においと健康

\title{
呼気中の水素・メタン 一消化管の活動を診る一
}

瓜田 純久*，杉本 元信*，三木 一正**

\begin{abstract}
現代の医療では非侵襲的に多くの情報を得ることが求められている. 採血さえも不要な呼気試験は, 検査 方法を工夫すると，多くの消化管情報を得ることができるが，その中心は水素・メ夕ンガスの測定である. 空腹時の呼気中水素は消化管発酵反応の指標と考えられているが，その再現性は低く，解釈は難しい．そこ で，試験食を負荷して呼気中水素・メタンガスの経時的な变化から病態を評価する方法が一般的である。非 吸収型の炭水化物, 食物繊維などは小腸で吸収されず, 大部分が大腸へ到達し, 腸内細菌の発酵反応で分解 される。この際発生する水素・メタンガスの時間, 量からガス発生部位を推定し, 消化管通過時間, 細菌の 異常増殖を診断することができる，発酵生成物が腹部症状を惹起する場合もあり，消化管での発酵の程度を 把握することは重要である. 今回, 臨床現場における水素・メタンガス測定の実際を述べる.
\end{abstract}

\section{1. はじめに}

医療現場では，二酸化炭素濃度の測定に代表されるよ うに，呼吸機能の情報を得る手段として呼気ガス測定が 行われてきた。一方, 消化管内腔には多数の気体が存在 し，その一部は吸収されて血液循環を介し，肺へ到達し て呼気中へ排出される。呼気中に出現するガス成分は 200 種類以上にのぼる1) が，消化管内腔で同定されてい る気体は少なく22，ごく一部である。生体内の水素・メ タンガスは細菌の発酵反応が唯一の起源之考えられてい る3．そこで種々の食物を負荷し，消化管で発生し，呼気 中へ排出される水素・メタンガスを測定することにより
消化吸収機能，消化管運動機能，および腸内細菌を評価 する方法が報告されている(4) 5).

\section{2. 消化管ガスの起源}

消化管内腔のガスの起源をまとめると，図一1のよう に大きく分類することができる、燕华装とともに内腔へ流 入するとされる窒素 $\left(\mathrm{N}_{2}\right)$ 抢よび酸素 $\left(\mathrm{O}_{2}\right)$, 腸内細菌や 口腔内細菌による発酵反応により生成される水素 $\left(\mathrm{H}_{2}\right)$, メタン $\left(\mathrm{CH}_{4}\right)$, 二酸化炭素 $\left(\mathrm{CO}_{2}\right)$, 酸化還元反応による $\mathrm{CO}_{2}$, 一酸化窒素 $(\mathrm{NO})$, 酵素反応による $\mathrm{CO}_{2}$, アンモニ ア $\left(\mathrm{NH}_{3}\right)$ ，一酸化炭素 $(\mathrm{CO})$ などが挙げられる 。厳密 には pH の低い胃内腔ではイオン化傾向の大きい物質が

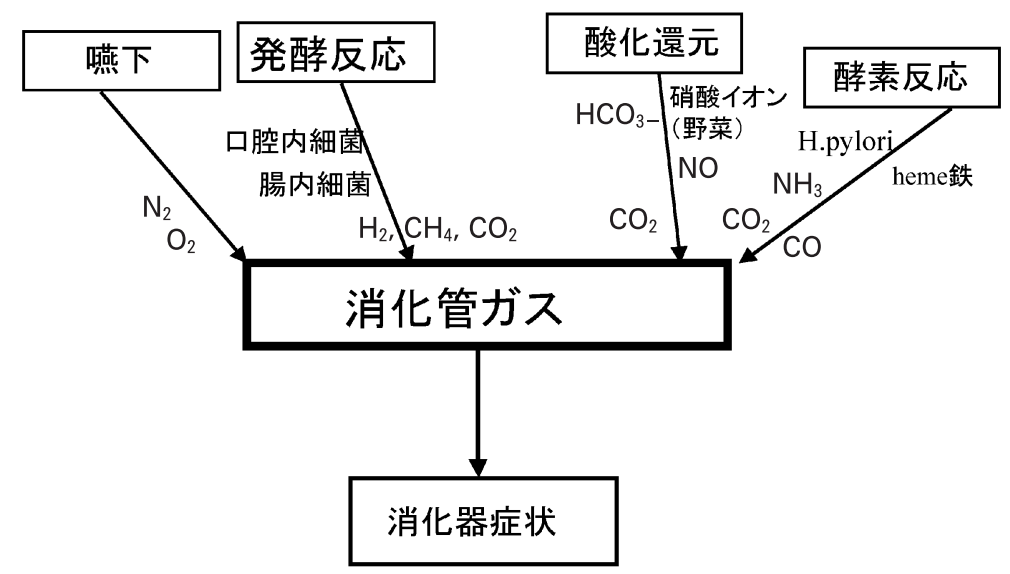

図-1 消化管ガスの起源

\footnotetext{
*瓜田 純久（うりた よしひさ， * 杉本 元信（すぎあと あとのぶ），**三木 一正（みき かずまさ）

* 東邦大学総合診療 - 急病科, ** 東邦大学消化器内科
}

干143-8541 東京都大田区大森西 6-11-1 
流入すると, 塩酸と反応して水素ガスが析出するため, 胃内腔であ水素ガスが発生している可能性がある ${ }^{6}$.

\section{3. 空腹時呼気中水素・メタンガス測定の意義}

呼気中水素・メタンガス濃度は消化管発酵反応の指標 として多くの報告がある7). ラクチュロースなど発酵基 質を負荷することによって水素ガス産生を促し, 呼気中 水素ガスを測定する方法 ${ }^{8}$ が一般的である。しかし，空 腹時に測定しても，呼気中水素・メタンガスが高值とな る症例むあり，何らかの原因で消化管での発酵反応充進 が持続しているものと考えられている ${ }^{9}$. 呼気中水素が ス濃度は食餌の影響を受けるが，メタンガス濃度は食餌 の影響は少ないと報告されている ${ }^{10)}$.

しかし，同一の被検者 34 例について早朝空腹時に 15 分間隔で呼気を採取して検討すると，水素ガスは $32 \%$ の症例, メタンガスは $50 \%$ で $3 \mathrm{ppm}$ 以上変化していた (図一2, 斜線部位の症例)。最大差は水素 $42 \mathrm{ppm}$, メ夕 ン $11 \mathrm{ppm}$ であった（図一2).すなわち, 空腹時において 屯呼気中水素・メタンガス濃度は变動が大きく, その解 釈は難しい。 また，1２週間隔で 6 回採取すると，水素 ガス 2〜57 ppm, メタンガス 1〜17 ppm の変化がみら
れ, 無症状の同一症例においても, 大きく変動すること が明らかとなった（図一-3）。また，基質を投与せずに腸 管に物理的刺激を与える内視鏡検査後に測定すると，水 素 1\%, メタン $12 \%$ の症例で $3 \mathrm{ppm}$ 以上上昇していた。

このように, 前日の食事内容の影響に加え, 起床後の 排便や歩行により消化管運動が促され, 腸内細菌と発酵 基質との接触状況が変化するため, 空腹時呼気中水素 · メタンガスは多くの要因により变化するものと思われ た ${ }^{11)}$. しかし, 持続的に空腹時呼気中水素・メタンガス が高值の症例では, 消化管運動機能, 腸内細菌, 消化吸 収能が変化している可能性が高い.

\section{4. 試験食摂取後の水素・メタンガス測定による評 価・診断}

食餌摂取後の呼気中水素・メタンガスを測定し，多く の症例で比較検討するためには，食事内容の統一が必要 である，通常の食材から調理した場合，炭水化物・脂 質・タンパク質の構成を一致させることは難しい。 そこ で，市販されている栄養補助食品のように，構成成分が 決まっているものを選び，「試験食」として用いている.

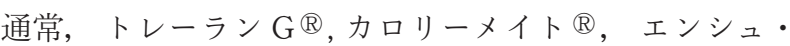
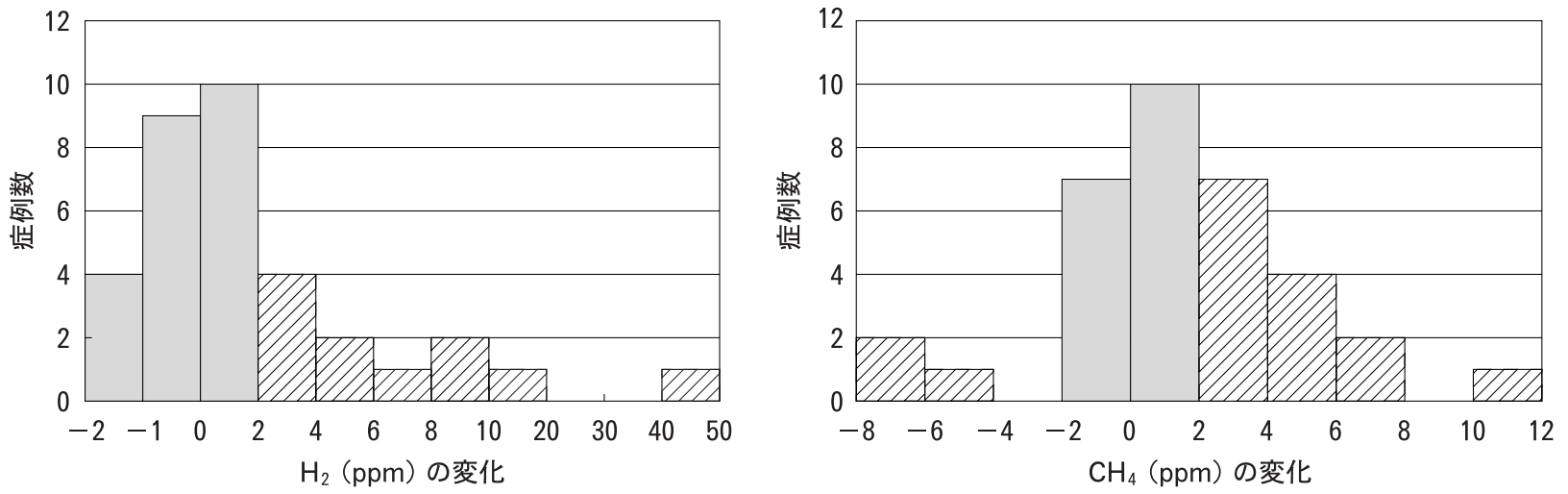

図－2 早朝空腹時に 15 分間隔で測定した呼気中水素（左図）およびメタンガス（右図）の差
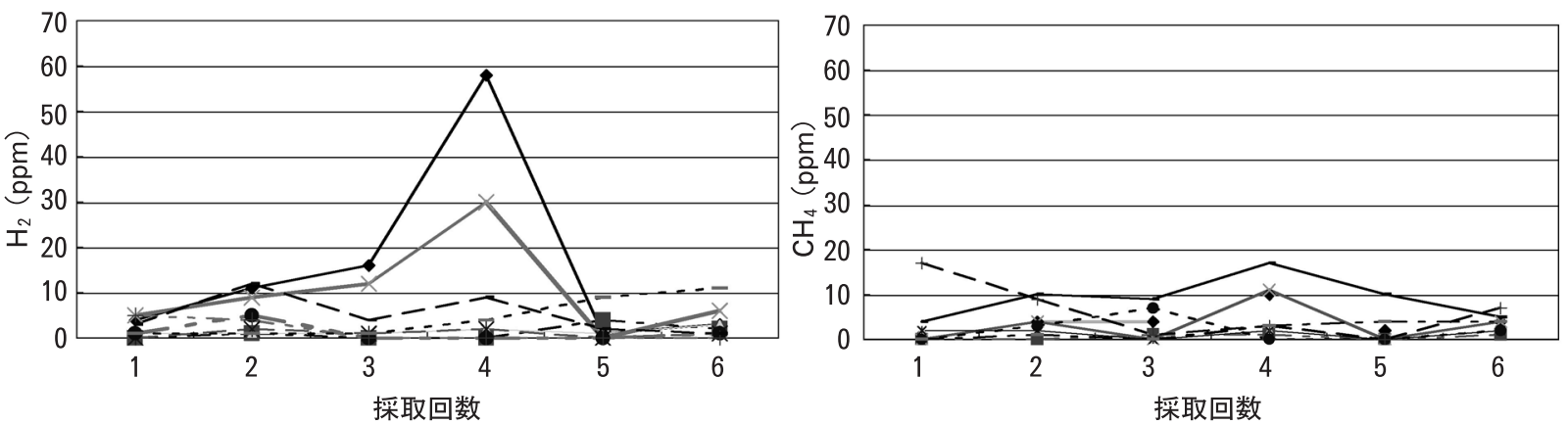

図－3 1 2 週間隔で 6 回採取した呼気中の水素（左）・メタンガス（右）濃度の変化 
アリキッド®，ラコール®などの液状食が用いられる.

以下に試験食摂取後の水素・メタンガス測定による診 断・評価について述べる.

\section{1 乳糖不耐症の診断}

乳糖不耐症では摂取した乳糖を分解する酵素が少ない ため，摂取後に血糖が上昇せず，消化吸収されなかった 乳糖が腸内細菌により分解され，水素ガス・短鎖脂肪酸 などが生成される。そのため, 腹部膨満感や下痢などの 症状が出現する。しかし, インスリン治療や経口糖尿病 薬を服用している糖尿病患者では, 乳糖不耐症がなくて も血糖は上昇しないため, 乳糖不耐症と診断されること になる。このような症例では, 呼気中水素ガス測定によ り診断が可能である ${ }^{12}$.

\section{2 指標としての消化管通過時間}

図ー4 に示すようにラクチュロース（Lactulose）など 非吸収性の糖質を投与した場合, 大腸へ到達して初めて 腸内細菌により分解される。このとき発生する水素ガス は吸収されて呼気中へ排出されるため, 呼気中水素が上 昇する時間は口から盲腸に達するまでの時間を反映す る。これが口-盲腸通過時間 (oro-cecal transit time,

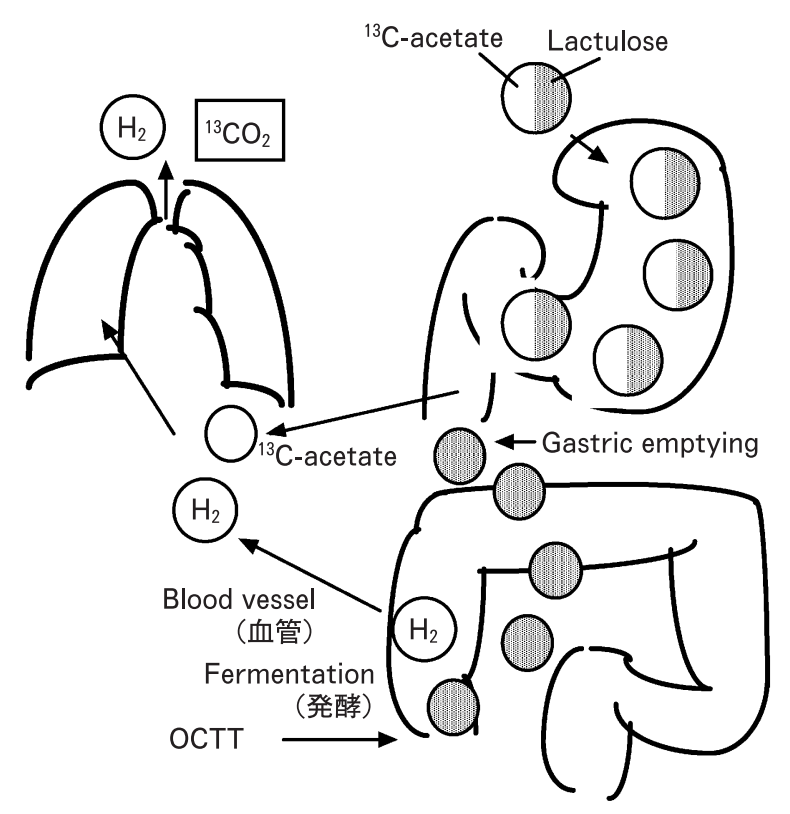

図-4 ${ }^{13} \mathrm{C}$-acetate 呼気試験とラクチュロース水素呼気 試験を組み合わせた消化管通過時間測定方法. ${ }^{13} \mathrm{C}$-acetate は小腸で速やかに吸収され, 呼気中 へ ${ }^{13} \mathrm{CO}_{2}$ として排出される.ラクチュロースは 大腸へ到達して細菌により分解され, 水素ガス が発生する。呼気中 ${ }^{13} \mathrm{CO}_{2}$ は胃排出速度 (Gastric emptying), 呼気中水素ガスは口-盲腸通過速 度の指標と考えられる。
OCTT）であり，消化管運動機能の指標のひとつと考え られている4).

\section{3 腸管洗浄の判定}

大腸内視鏡検査では約 $2000 \mathrm{~mL}$ のポリエチレングリ コール液を飲用し，腸管を洗浄後に内視鏡を挿入する. この際，腸管が十分に洗浄されたかどうか，便の性状に よって判定する。しかし，便が比較的透明になっても， 深部結腸では洗浄が不十分な場合もしばしば経験する。 そこで，呼気中水素ガスを経時的に測定すると，腸管が 十分洗浄された場合, 呼気中水素ガスは非常に低值とな り，腸管洗浄の判定が容易である ${ }^{13)}$.

\section{4 消化吸収障害の診断}

炭水化物は通常ほとんどが小腸で消化吸収されるが, 消化吸収障害がある場合，あるいは食物繊維などの難消 化性炭水化物を投与した場合, 多くの炭水化物は大腸ま で到達し，腸内細菌により発酵反応を受け，水素，二酸 化炭素，短鎖脂肪酸などが生成される。そのため，炭水 化物負荷後の呼気中水素ガス上昇は消化吸収障害を反映 した変化と考えられる。糖尿病の診断に用いられる $75 \mathrm{~g}$ 糖負荷試験では 34\%の症例で $10 \mathrm{ppm}$ 以上の呼気中水 素ガス濃度上昇がみられた ${ }^{14)}$ 。多くの症例では投与され た糖がすべて吸収されておらず，血糖の变化に何らかの 影響を及ぼしているものと考えられる。

\section{5 異常細菌増殖（bacterial overgrowth）の診断}

通常，炭水化物は小腸で吸収されるが，小腸に細菌が 増殖すると吸収される前に細菌により分解され, 水素ガ スが発生する. 即ち, 食事摂取後早期に呼気中水素ガス 上昇がみられた場合，小腸での bacterial overgrowth が示唆される。図-5に示すように， $75 \mathrm{~g}$ 糖負荷後に呼 気中水素ガス上昇がみられた症例のなかで， $75 \%$ が 20 〜 40 分と早期から上昇した ${ }^{14)}$.

\section{6 通過障害の有無}

クローン病, 大腸癌など, 腸管の狭窄などが生じる病 態でも, bacterial overgrowth が高率にみられる。呼気 中水素・メタン測定により，通過障害の有無が推定で き, 大腸癌と呼気中メタンガス上昇の関連を述べた報告 が多い15).

\section{5. 消化管内腔の水素・メタンガスと疾患}

水素・メタンガスの起源が消化管内細菌の発酵反応で あることから，呼気中の気体を測定するよりも，消化管 


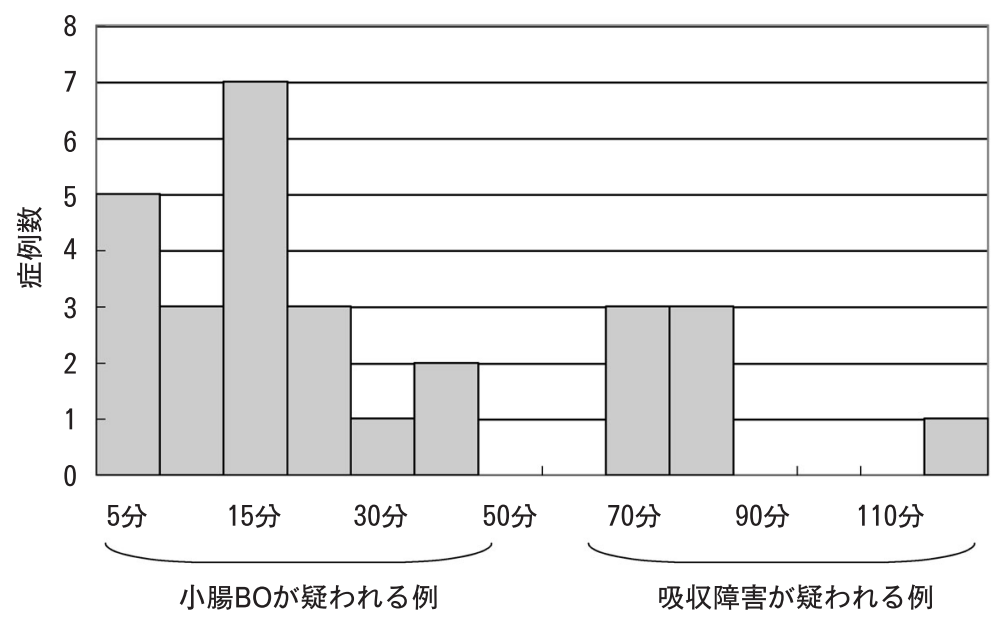

図－5 $75 \mathrm{~g}$ 糖負荷試験において呼気中水素・メタンガス濃度が $10 \mathrm{ppm}$ 以上上昇した時間

内腔の気体を直接測定することにより，気体の吸収・代 謝・排出の影響を受けずに消化管環境を評価することが 可能である，以下にその具体例を述べる.

\section{1 萎縮性胃炎の診断}

ピロリ菌（Helicobacter pylori）が発見される前から， 酸分泌の低下した症例では多くの細菌が胃内に存在する ことが報告されている(15) 16)。胃酸は胃・小腸での細菌 増殖に防御的に作用しているため, 酸分泌が低下した萎 縮性胃炎では上部消化管において bacterial overgrowth が起こっている可能性が高い17) 18). 実際に内視 鏡を用いて胃および十二指腸内腔の気体を採取すると， 多くの症例で水素・メタンガスが検出された。萎縮性胃 炎は内視鏡検査で評価すると closed type (C-1, C-2), open type（O-1，O-2，O-3）と進展するが, 図-6に示 したように萎縮の進展した O-3 型の症例で十二指腸内 腔の水素ガスが高値であった。胃内腔および呼気中水素 ガス濃度は萎縮の程度と差はなかった。萎縮性胃炎にお いては，胃内腔よりも小腸での bacterial overgrowth が高率に起こっていると考えられる。

\section{2 消化管運動と bacterial overgrowth の評価}

便秘など，細菌之発酵気質（食餌）との接触時間が延 長する病態では水素ガス発生が六進する. ${ }^{13} \mathrm{C}$-acetate 呼 気試験にて評価した胃排出遅延群と正常群の胃内腔の水 素・メタンガス濃度を比較すると, 図ー7 のように胃内 腔水素ガス濃度は胃排出遅延群で高值であり, 呼気中水 素ガス濃度も同様であった ${ }^{3)}$. 即ち, 胃排出が遅延した 場合, 胃内腔だけではなく, 全消化管において発酵反応 が六進していた.

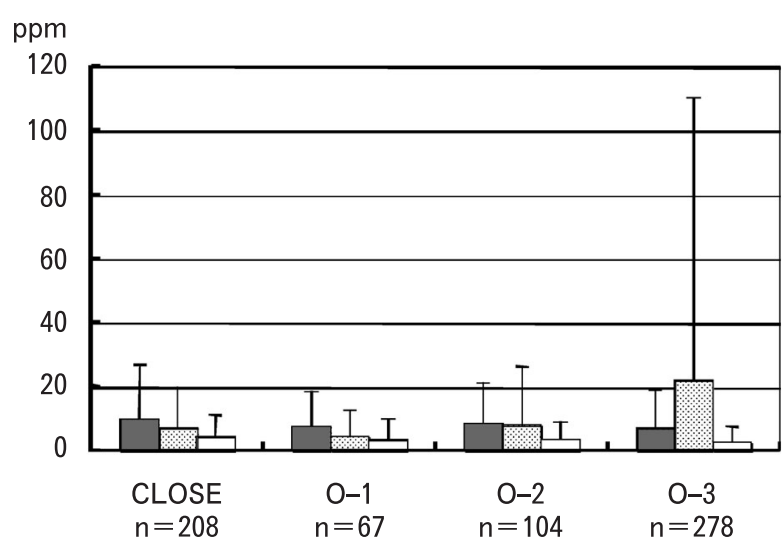

口胃内腔眯十二指腸内腔呼気

図-6 萎縮性胃炎の進展と消化管内腔 - 呼気中水素ガ スの変化

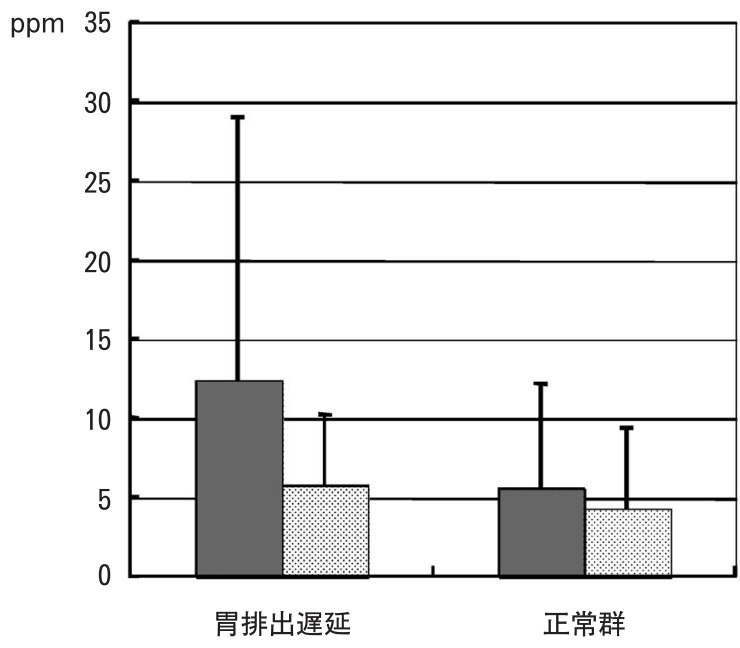

口胃内腔前水素 圆胃内腔前メタン $p=0.09$

図－7 胃排出速度と胃内腔水素・メタンガス濃度 


\section{3 食後のガス発生による評価}

消化管内腔におけるガス発生は，細菌が食餌中の発酵 基質を発酵に利用することによる。そこで空腹時に消化 管ガスが少ない症例でも，食後に大量のガスが発生して 腹部膨満感を生じる場合が予想される.内視鏡下に普通 牛乳 $20 \mathrm{~mL}$ を散布し，10〜15 秒後に胃内腔の気体を採 取して水素ガス濃度を測定すると，5.5\%で水素ガスの 上昇がみられた。細菌の多い腸管内ではさらに高率にガ スが発生する可能性が高い. $200 \mathrm{cc}$ の液状食を飲用後, 経時的に 240 分まで呼気中水素ガス濃度を測定したとこ ろ, 半数以上の症例で $3 \mathrm{ppm}$ 以上の上昇がみられた ${ }^{5)}$.

\section{6. 水素・メタンガスとともに生成される物質の影響}

発酵反応では水素, 二酸化炭素, 短鎖脂肪酸が生成さ れる。この短鎖脂肪酸には食後の一過性下部食道括約筋 弛緩の増加, 胃排出抑制などの作用があり, 逆流性食道 炎を惹起する可能性が報告されている ${ }^{19)}$. 我々の検討で あ, 逆流性食道炎患者では消化管発酵の亢進している症 例が有意に多かった ${ }^{20)}$.

消化管内腔の細菌は H. pylori のように粘膜に接着し て増殖し, 炎症を惹起しなければ病原性はほとんよ゙ない と考えられてきた。しかし発酵生成物が消化管機能に影 響を及ぼし, 消化器症状を惹起する可能性があり, 胃内 腔に持続的に流入する口腔内細菌など, 胃内通過菌の作 用も検討が必要である.

\section{7. おわりに}

呼気および消化管内腔の水素・メタンガスを測定する ことにより，消化管内腔の環境を推定できることを述べ た. 医療現場では, 固体（病理組織診断, 粪便検査など） や液体（血液, 尿, 胃液, 唾液など）を試料とした検査 が大部分を占め, 呼気や消化管内腔ガスなどの気体成分 はほとんど利用されていなかった。しかし，採血さえも 不要な呼気測定は被検者にも負担がほとんどなく, 繰り 返し施行できるため, 試験食や方法を工夫することによ り，さらに多くの情報を得ることができ，今後のさらな る発展が期待される。

キーワード : 腸内ガス, 乳糖不耐症, 食物繊維, 便秘, 大腸疾患

\section{参考文献}

1 ) Phillips, M., Herrera, J., Krishnan, S., Zain, M., Greenberg, J., Cataneo, R.N. : Variation in volatile organic compounds in the breath of normal humans, J Chroma- togr B Biomed Sci Appl, 729, 75-88, (1999).

2 ) 高木高明, 森下芳行：発酵之腐敗. 島崎順雄, 他編 : (1976), 病気の生化学 13B, 消化器 ; p 31, 中山書店.

3) 瓜田純久, 日毛和男, 鳥居尚隆, 菊池由宣, 神田映子, 倉 形秀則, 笹島雅彦, 三木一正 : 呼気試験による慢性胃炎の 解析. 消化器科, 39, 154-158, (2004).

4 ) Urita, Y., Hike, K., Torii, N., Kikuchi, Y., Sasajima, M., Miki, K. : Efficacy of lactulose plus ${ }^{13} \mathrm{C}$-acetate breath test in the diagnosis of gastrointestinal motility disorders, J Gastroenterol, 37, 442-448, (2002).

5 ) 瓜田純久, 菊池由宣, 日毛和男, 鳥居尚隆, 神田映子, 笹 島雅彦，松崎浩司，三木一正：内視鏡下検査食負荷後の呼 気・消化管内腔の気体分析による消化吸収試験. 消化之吸 収, 24, 20-23，(2001).

6 ) Sack, D.A., Stephensen, C.B. : Liberation of hydrogen from gastric acid following administration of oral magnesium, Dig Dis Sci, 30, 1127-1133, (1985).

7 ) Levitt, M.D., Hirsh, P., Fetzer, C.A., Sheahan, M., Levine, A.S. : $\mathrm{H} 2$ excretion after ingestion of complex carbohydrates, Gastroenterology, 92, 383-389, (1987).

8 ) Rhodes, J.M., Middleton, P., Jewell, D.P. : The lactulose hydrogen breath test as a diagnostic test for smallbowel bacterial overgrowth. Scand J Gastroenterol, 14, 333-336, (1979).

9 ) Perman, J.A., Modler, S., Barr, R.G., Rosenthal, P. : Fasting breath hydrogen concentration: normal values and clinical application, Gastroenterology, 87, 13581363, (1984).

10) Bjorneklett, A., Jenssen, E. : Relationships between hydrogen $\left(\mathrm{H}_{2}\right)$ and methane $\left(\mathrm{CH}_{4}\right)$ production in man, Scand J Gastroenterol, 17, 985-992, (1982).

11）瓜田純久, 日毛和男, 鳥居尚隆, 菊池由宣, 倉形秀則, 神 田映子，笹島雅彦，松崎浩司，三木一正 : 食事摂取による 呼気中水素 ・メタンガス濃度の变動. 消化と吸収, 26, 1720, (2004).

12）寺田明功, 中村光男 : 糖尿病における呼気中水素濃度測 定の臨床的意義, 消化と吸収, 24，13-19，(2001）.

13) Urita, Y., Hike, K., Torii, N., Kikuchi, Y., Kanda, E., Sasajima, M., Ariki, H., Miki, K. : Hydrogen breath test as an indicator of the quality of colonic preparation for colonoscopy, Gastrointest Endosc, 57, 174-177, (2003).

14）瓜田純久, 日毛和男, 鳥居尚隆, 菊池由宣, 神田映子, 倉 形秀則，笹島雅彦，三木一正 : 糖尿病に扮けるグルコース 水素呼気試験の意義. 消化と吸収，27，42-45，(2004).

15) Gray, J.D., Shiner, M. : Influence of gastric $\mathrm{pH}$ on gastric and jejunal flora, Gut, 8, 574-579 (1967).

16) Drasar, B.H., Shiner, M., McLeod, G.M. : Studies on the intestinal flora ; The bacterial flora of the gastrointestinal tract in healthy and achlorhydric persons, Gastroenterology, 56, 71-79, (1969).

17) Holt, P.R. : Clinical significance of bacterial overgrowth in elderly people, Age Ageing, 21, 1-4, (1992).

18) Howden, C.W., Hunt, R.H. : Relationship between gastric secretion and infection (progress report), Gut, 28, 
96-107, (1987).

19) Piche, T., des Varannes, S.B., Sacher-Huvelin, S., Holst, J.J., Cuber, J.C., Galmiche, J.P. : Colonic fermentation influences lower esophageal sphincter function in gastroesophageal reflux disease, Gastroenterology, 124, 894
-902 (2003).

20）瓜田純久, 日毛和男, 鳥居尚隆, 菊池由宣, 神田映子, 倉 形秀則, 笹島雅彦, 三木一正. 逆流性食道炎と消化管発酵. 消化と吸収，27，13-15，(2004).

\title{
Breath hydrogen and methane measurements in clinical practice
}

\author{
Yoshihisa URITA*, Motonobu SUGIMOTO*, Kazumasa MIKI** \\ *,** Department of General Medicine and Emergency Care, and Division of Gastroenterology \\ and Hepatology, Toho University School of Medicine, \\ 6-11-1, Omori-nishi, Ota-ku, Tokyo 143-8541 Japan
}

\begin{abstract}
Breath hydrogen $\left(\mathrm{H}_{2}\right)$ and methane $\left(\mathrm{CH}_{4}\right)$ measurements are widely used to evaluate carbohydrate malabsorption, bacterial overgrowth and oro-cecal transit time. It was reported that 2 $-20 \%$ of carbohydrates escape small intestinal absorption and reached the colon. Based on this fact, colonic fermentation is considered to be present more frequency than expected. If bacteria exist in the small intestine or unabsorbed carbohydrates reach the cecum, the glucose ingested will be metabolized by gut flora and $\mathrm{H}_{2}$ or $\mathrm{CH}_{4}$ is produced in the intestinal tract. Because bacteria represent the sole source of gut $\mathrm{H}_{2}$ and $\mathrm{CH}_{4}$, fasting breath $\mathrm{H}_{2}$ and $\mathrm{CH}_{4}$ gases have been used as markers of colonic fermentation. Methanogenic bacteria utilize $\mathrm{H}_{2}$, carbon dioxid, and then synthesize $\mathrm{CH}_{4}$. As gastric acid plays an important part in the prevention of bacterial colonization of the stomach and the small intestine, reduction of gastric acid secretion often results in bacterial overgrowth. If the fermentation occurs in the stomach or proximal small intestine, it inhibits gastric and pancreatic secretions, and also influences lower esophageal sphincter function in gastroesophageal reflux disease. Although breath tests such as measuring fasting or postprandial $\mathrm{H}_{2}$ concentrations are noninvasive, avoiding the risk of sampling error, the site of overgrowth cannot be identified. Therefore, we also measured intragastric and intraduodenal $\mathrm{H}_{2}$ and $\mathrm{CH}_{4}$ concentrations to determine the site of fermentation. In the future, the expansion of $\mathrm{H}_{2}$ and $\mathrm{CH}_{4}$ measurement may make it possible that breath testing may be adopted as a primary approach to the diagnosis of digestive diseases which have avoided older invasive methods.
\end{abstract}

Key words : breath hydrogen, breath methane, gastrointestinal diseases, bacterial overgrowth, fermentation, carbohydrate malabsorption 